Minority Rules 
B O DY,

COMMODITY,

TEX T

Studies of Objectifying Practice

A series edited

by Arjun Appadurai,

Jean Comaroff, and

Judith Farquhar 


\section{Minority Rules}

The Miao and the Feminine

in China's Cultural Politics

Louisa Schein

Duke University Press

Durham \& London

2000 
(C) 2000 Duke University Press

All rights reserved

Printed in the United States of America on acid-free paper @ Designed by C. H. Westmoreland

Typeset in Dante by Tseng Information Systems, Inc.

Library of Congress Cataloging-in-Publication Data appear on the last printed page of this book.

Portions of the following chapters have been previously published: chapters 4 and 5, in Modern China 23, no. I (1997):

69-98; chapter 9, in Cultural Anthropology 14, no. 3 (1999): 36r-395. 
To

my parents

Mary and Ed

and to

Ernie, Sophia, and

Little 'Nesto 
